\title{
National Culture and the Thematic Structure OF News TeXTs
}

\begin{abstract}
The objective of this article is to examine the relationship between the thematic structure of news texts and the context of national culture in which they were produced. The study, though being part of a larger project, concerns only two front-page articles published in two national Polish and British dailies.

The first stage of the study refers to an examination and determination of the thematic structure of news text, based on Teun A. van Dijk's analysis of international and national news in the press. In the second stage of the analysis, the results of the study are confronted with the cultural dimensions model proposed by Hofstede and Hofstede and the scores for Poland and United Kingdom, as well as with Hall's insights into the differences between high-context and lowcontext cultures.
\end{abstract}

\section{Key words}

Thematic structure; news texts; cultural differences; cultural dimensions; lowcontext cultures; high-context cultures

\section{Introduction}

In this article we are going to study the relationship between discourse structures in news texts and cultural patterns specific to two European countries, namely Poland and the United Kingdom. The objective of this article is to find out if national culture (understood as a system of values specific to a nation) influences the thematic structure of news texts, i.e. to examine if certain culture-related preferences play a role in the choice of the topics, their order and extent of coverage. The analysis will be performed with the use of discourse analysis tools proposed by van Dijk 
in his study of international and national news in the press (1988). The results of the qualitative part of the analysis will be then supported by some quantitative data concerning the most important topics discussed in the studied texts. However, the quantitative data will constitute only a background for the interpretation of the similarities and differences found in the texts during the first stage of the analysis.

The study material used in this paper is a part of a larger project including all texts from 20 editions of a British daily, The Guardian, and 20 editions of a Polish daily, Gazeta Wyborcza, gathered on weekdays between January 14 and February 10,2010 . The project concerns the study of the influence of national culture on news texts. It embraces a quantitative analysis of most frequent topics, special reports and editorials, the structure of interviews, obituaries, story attribution and the order of sections found in the dailies. The study also includes a detailed analysis of one subject, namely the Haitian earthquake which happened on January 12,2010. All articles published in both dailies within the studied period were examined with regard to their number and size. Also the size of the headings and the number of photographs were studied. The obtained data were then put into the context of cultural differences between the two nations.

However, as such large corpora (well over 2,000 articles) could not be subjected to a qualitative analysis, which will be the focus of this article, only two corresponding texts, representative of the whole sample, were selected for this undertaking. It needs to be underlined, though, that performing the qualitative analysis, the researchers had in mind the context of the whole project and that the previously obtained data provided them with a broader perspective on the new findings.

The selected texts were the first articles to cover the subject of the Haitian earthquake; they were published on the same day - January 14, 2010. While the Polish text takes up only the front page of the issue, the British one is continued on page three. Nevertheless, the whole texts were subjected to the analysis. The selection of the two dailies, The Guardian and Gazeta Wyborcza, was dictated by the similarity of their political alignment and readership profile.

The data obtained in the course of the analysis of the thematic structure of the texts were then put in the context of cultural differences. We looked for cultural patterns specific to the Polish and/or British culture to assess if the differences or similarities occurring between the texts were culture-related. The cultural patterns were identified within the model of cultural dimensions (Hofstede and Hofstede 2005) and the theory of low-context and high-context societies (Hall 1976). Therefore, it can be easily stated that the theoretical framework of this paper integrates discourse analysis with contemporary research in pragmatics.

As the study includes texts written and published in two languages, namely Polish and English, all examples taken from the Polish article will be translated into English. However, to retain the original meaning of the propositions the translations will be quite literal.

All in all, the study attempts to broaden our knowledge on how national culture influences the structure of language. It rests upon a belief that a culture-conscious 
language user is able to communicate more effectively in an international environment knowing what barriers he or she has to overcome. The choice of news texts as research material seemed obvious, as we agree with Bell that "news is a major register of language" (Bell 1998: 65).

\section{Theoretical background and research methods}

As mentioned above, the analysis presented in this paper does not merely focus on the thematic structures of news texts, but also on processes and representations involved in the production and comprehension of news discourse, and especially on the employment of cultural values during such processing.

Some of the first scholars to study the role that the cultural context plays in discourse processing were Kintsch and Greene (1978), who proved that the superstructure schema specific to a given culture facilitates the comprehension of stories. Later work was carried out by Reynolds et al. (1982), who examined the relationship between cultural schemata and reading comprehension, and by Detweiler et al. (1983), who studied the way that cultural differences influence descriptions of various situations. More recent studies into the impact of cultural context on discourse processing include elaborate works by Bremer et al. (1996), Duszak (1998), Collier (2000), Scollon and Scollon (2001), Barker and Galasiński (2001), Fitzgerald (2003) and Wierzbicka (2003) to name just a few.

In this paper, following the work of Barker and Galasiński, we want to reveal the "discursive construction of cultural forms" (2001: 1), though instead of tools used in CDA we simply focus on the analysis of the thematic structure of the studied texts, where the structure is understood as "the hierarchical organization of themes or topics of a text, theoretically accounted for in terms of semantic macrostructures" (van Dijk 1988: 72).

The analytical procedure adopted in this study is based on van Dijk's analysis of international and national news in the press (1988). We start with a list of the most important topics in each story to be able to "determine the themes in each news discourse and to establish their conditional (linear) and hierarchical relationships and their semantic specification in the text" (van Dijk 1988: 73). Then, we discuss the headlines of the studied articles, identify topics mentioned in the texts and associate them with hypothetical semantic functions (van Dijk 1988: 76). Last but not least, we organize the topics into hierarchical thematic structures presented in a form of a tree diagram and compare them.

At the next stage of the analysis the obtained qualitative data are put in the cultural context, which means that the observed differences and similarities between the Polish and British structures are juxtaposed with cultural values specific to Polish and British cultures. The values are identified within the framework of low-context and high-context cultures (Hall 1976) and cultural dimensions (Hofstede and Hofstede 2005), i.e.: power distance (PDI), individualism vs. collectivism (IDV), masculinity vs. femininity (MAS), uncertainty avoidance (UAI) and 
long-term vs. short-term orientation (LTO). In our analysis we follow the authors' conclusions that cultural values can be measured in each dimension and treat the scores for Poland (PDI 68, IDV 60, MAS 64, UAI 93, LTO 32) and United Kingdom (PDI 35, IDV 89, MAS 66, UAI 35, LTO 25) as cultural markers of the two nations. The assignment of high- or low-context characteristics to the cultures in question seems more complex. While British culture has been explicitly categorized as a low-context culture (Hall 1976), the categorization of Polish culture, being situated in the middle of the high-context/low-context continuum, is not that obvious. However, as many scholars (Wood 2004, Ferris and Godar 2006, Gannon and Pillai 2010) classify Polish culture as high-context, such a position will be adopted in this study.

It is important to underline what the cultural dimensions concern, and that is: "the extent to which the less powerful members of institutions and organisations within a country expect and accept that power is distributed unequally" (Hofstede and Hofstede 2005: 46) (PDI), "the extent to which the members of a culture feel threatened by ambiguous or unknown situations" (Hofstede and Hofstede 2005: 167) (UAI) and "the power of the group" (Hofstede and Hofstede 2005: 74) (IDV). They also contrast "the desirability of assertive behaviour against the desirability of modest behaviour" (Hofstede and Hofstede 2005: 116) (MAS) with "the fostering of virtues oriented toward future rewards - in particular perseverance and thrift" (Hofstede and Hofstede 2005: 210) and "the fostering of virtues related to the past and present - in particular, respect for tradition, preservation of 'face' and fulfilling social obligations" (Hofstede and Hofstede 2005: 210) (LTO). Even though the model is based on a study of organisational culture, we presume it is applicable to an investigation of news texts as the object of our research is not culture itself but the relationship between culture and language. It seems a reasonable assumption that the culture-specific characteristics of a language will be observable both in business and news discourse.

One should also be reminded that Hall's contexting process (1976: 86) refers to the function of culture which is to "provide a highly selective screen between man and the outside world" (1976: 85). Therefore, the common knowledge, experience and expectations exert greater impact on communication in high-context cultures than in low-context cultures. Unfortunately, due to the limited size of this article a more detailed characteristic of the criteria facilitating the classification of cultures cannot be presented.

\section{Analysis of the thematic structure of news texts}

Following the research method described above we created a list of the most important themes in the story of the earthquake in Haiti:

1. There was a 7.0 magnitude earthquake in Haiti on January 12, 2010. (both newspapers) 
2. The earthquake caused many buildings to collapse. (both newspapers)

3. Many people were trapped under the rubble. (both newspapers)

4. Aftershocks rocked the city. (both newspapers)

5. Survivors tried to rescue the victims from under the debris. (both newspapers)

6. Haiti's President appealed for help. (only The Guardian)

7. International aid was offered to Haiti. (only The Guardian)

Unlike the texts analyzed by van Dijk (1988), the articles concerning the Haitian earthquake are focused almost entirely on the main events, their participants and results, and not on the context or the background of the events. The only information given by both dailies that could be categorized as such is the information on Haiti being the poorest country in the western hemisphere and, in case of The Guardian, the information on the cause of such great shaking at the surface, namely the tremor being shallow.

Before a detailed thematic analysis of the articles is presented, we will focus our attention on the headlines. In the Polish daily, apart from the main headline Koszmar Haiti [Haiti's nightmare], capitalized, there is one subheading placed above the headline: Ofiar trzęsienia ziemi może być ponad 100 tys. [There may be over 100,000 earthquake casualties] and one below the headline: $W$ przeszło $d w u-$ milionowej stolicy Port-au-Prince zawality się setki, a być może tysiace domów. Wczoraj Haitańczycy najczęściej golymi rękami odkopywani zasypanych [In the capital with over 2 million inhabitants, Port-au-Prince, there collapsed hundreds or even thousands of houses. Yesterday Haitians dug out the buried most often with their bare hands.]

Accordingly, in The Guardian, below the headline Haiti's day of devastation, not capitalized, there are three subheadings: Fears that quake death toll could rise above 100,000; Frantic search for survivors in ruined schools and hospitals; and Biggest tremor in 200 years struck nine miles from capital.

Since in both news items the lead is not graphically distinguished and seems to be an integral part of the main body of the text, it will not be discussed separately.

The topics presented in Table 1 and Table 2 were identified intuitively, based on the content of sentences and paragraphs. The semantic functions, to which the topics were associated, represent information on the main events, their circumstances, time, place, results and consequences, as well as the participants, causes and context of the story. According to van Dijk these are the categories that describe a cognitive situational model, in this case, a situational model of the event of an earthquake. It is necessary to bear in mind that the lists of topics in Table 1 and Table 2 are not yet representing the thematic structures of the texts. However, the lists are a salient source of information on the order of occurrence of individual topics and thus their relevance - a key point in our culturally-oriented analysis.

The topics mentioned in the headline are typed in bold. 
Table 1. Topics and topic categories in the thematic structure of a front page article published in Gazeta Wyborcza (January 14, 2010)

\begin{tabular}{|c|c|c|}
\hline & Topic & Topic category \\
\hline 1a. & \begin{tabular}{|l|} 
Ofiar może być ponad 100 tys. \\
'Death toll might be above 100 thousand'
\end{tabular} & result / consequence \\
\hline $2 \mathrm{a}$. & $\begin{array}{l}\text { W Port-au-Prince zawaliły się setki lub nawet tysiące domów } \\
\text { 'In Port-au-Prince there collapsed hundreds or even thousands } \\
\text { of houses' }\end{array}$ & place / result \\
\hline $3 a$. & \begin{tabular}{|l|} 
Wezoraj ludzie odkopywali innych gołymi rękami \\
'Yesterday people dug out the buried with bare hands' \\
\end{tabular} & consequence / time \\
\hline $4 a$. & $\begin{array}{l}\text { Najbiedniejsze państwo na półkuli zachodniej } \\
\text { 'The poorest country in the western hemisphere' }\end{array}$ & context \\
\hline $5 \mathrm{a}$. & $\begin{array}{l}\text { Kraj zniszczony } \\
\text { 'Country destroyed' } \\
\end{array}$ & result \\
\hline $6 a$. & $\begin{array}{l}\text { Największe trzęsienie ziemi od } 240 \text { lat } \\
\text { 'Biggest earthquake in } 240 \text { years' } \\
\end{array}$ & event / history \\
\hline $7 \mathrm{a}$. & \begin{tabular}{|l} 
Według prezydenta może być od 30 do 50 tys. ofiar \\
'According to the president 30 to 50 thousand might be dead'
\end{tabular} & result \\
\hline $8 \mathrm{a}$. & $\begin{array}{l}\text { Ofiar może być ponad } 100 \text { tys. } \\
\text { 'Death toll might be above } 100 \text { thousand' } \\
\end{array}$ & result / consequence \\
\hline 9a. & \begin{tabular}{|l|}
7 stopni w skali Richtera \\
'7.0 magnitude' \\
\end{tabular} & $\begin{array}{l}\text { event / circumstanc- } \\
\text { es }\end{array}$ \\
\hline 10a. & \begin{tabular}{|l|} 
We wtorek o 17 \\
'On Tuesday, at $5 \mathrm{pm}$ ' \\
\end{tabular} & time \\
\hline $11 \mathrm{a}$. & $\begin{array}{l}\text { Wypadły szyby, ściany mocno się trzęsły } \\
\text { 'Windows fell out, walls were trembling hard' }\end{array}$ & event \\
\hline 12a. & $\begin{array}{l}\text { Zawaliły się setki, a nawet tysiące domów w stolicy } \\
\text { 'Hundreds or even thousands of houses collapsed in the capital' }\end{array}$ & result \\
\hline $13 \mathrm{a}$. & $\begin{array}{l}\text { Zawaliły się domy poza miastem } \\
\text { 'Houses outside the city collapsed' }\end{array}$ & event \\
\hline $14 \mathrm{a}$. & $\begin{array}{l}\text { Samochód spadał po zboczu } \\
\text { 'A car fell down a hillside' } \\
\end{array}$ & event \\
\hline $15 \mathrm{a}$. & $\begin{array}{l}\text { Chmura kurzu zniknęła po pół godziny } \\
\text { 'A cloud of dust vanished half an hour later' }\end{array}$ & event \\
\hline $16 a$. & $\begin{array}{l}\text { Ocaleni spędzili noc na ulicach } \\
\text { 'Survivors spent the night in the streets' } \\
\end{array}$ & consequence \\
\hline $17 \mathrm{a}$. & $\begin{array}{l}\text { Ludzie spali na ziemi, rozpalali ogniska } \\
\text { 'People slept on the ground, built bonfires' } \\
\end{array}$ & consequence \\
\hline $18 \mathrm{a}$. & $\begin{array}{l}28 \text { wstrząsów wtórnych, nawet o sile } 6 \text { stopni w skali Richtera } \\
\text { '28 aftershocks, some } 6.0 \text { magnitude' }\end{array}$ & $\begin{array}{l}\text { event / circumstanc- } \\
\text { es }\end{array}$ \\
\hline 19a. & $\begin{array}{l}\text { Budynek parlamentu, głównego urzędu podatkowego, szkoły i } \\
\text { szpitale zawalone } \\
\text { 'The buildings of parliament, tax office, schools and hospitals col- } \\
\text { lapsed' }\end{array}$ & result \\
\hline $20 \mathrm{a}$. & \begin{tabular}{|l|} 
Budynki pełne rannych \\
'Buildings are packed with the injured' \\
\end{tabular} & consequence \\
\hline 21a. & $\begin{array}{l}\text { Brak sprawnej akcji ratowniczej w ruinach parlamentu } \\
\text { 'No rescue operations in the parliament's rubble' }\end{array}$ & consequence \\
\hline
\end{tabular}




\begin{tabular}{|l|l|l|}
\hline & Topic & Topic category \\
\hline 22a. & $\begin{array}{l}\text { Kely Bastien, przewodniczący Senatu, pod gruzami podobno żywy } \\
\text { 'Kely Bastien, the Senate chairman, is under rubble, allegedly alive' }\end{array}$ & result / actor \\
\hline 23a. & $\begin{array}{l}\text { Nie żyje Serge Miot, arcybiskup Port-au-Prince } \\
\text { 'Serge Miot, the archbishop of Port-au-Prince, is dead' }\end{array}$ & result / actor \\
\hline 24a. & $\begin{array}{l}\text { Siedziba przedstawicielstwa Banku Światowego zawaliła się z z } \\
\text { kilkudziesięcioma osobami w środku } \\
\text { 'Headquarters of the World Bank collapsed with less than a hundred } \\
\text { people inside' }\end{array}$ & result \\
\hline 25a. & $\begin{array}{l}\text { Nie żyje Hedi Annabi, szef misji ONZ } \\
\text { 'Hedi Annabi, the head of the UN mission, is dead' }\end{array}$ & result / actor \\
\hline 26a. & $\begin{array}{l}\text { Stacje telewizyjne pokazują zdjęcia ze stolicy } \\
\text { 'TV stations show footage from the capital' }\end{array}$ & $\begin{array}{l}\text { consequence } \\
\text { podnoszą przechodnie poszukujący bliskich } \\
\text { 'People camp out in the streets next to bodies covered with tarpau- } \\
\text { lin, which is picked up by the passers-by searching for their rela- } \\
\text { tives' }\end{array}$ \\
\hline 27a. & $\begin{array}{l}\text { Ludzie koczuja na ulicach obok ciał przykrytych brezentem, który } \\
\text { Przysypani odkopywani są rękami i łopatami } \\
\text { 'The buried are dug out with spades or bare hands' }\end{array}$ \\
\hline 29a. & $\begin{array}{l}\text { Brak policji i ekip ratowniczych; pracują rodziny, sąsiedzi } \\
\text { 'No police or rescue teams; families and neighbours do the work' }\end{array}$ & consequence \\
\hline
\end{tabular}

Table 2. Topics and topic categories in the thematic structure of a front page article published in The Guardian (January 14, 2010)

\begin{tabular}{|l|l|l|}
\hline & Topic & Topic category \\
\hline 1b. & Death toll might be above 100,000 & result / consequence \\
\hline 2b. & Survivors looked for in ruined schools and hospitals & consequence \\
\hline 3b. & Biggest tremor in 200 years & event / history \\
\hline 4b. & Nine miles from Port-au-Prince & place \\
\hline 5b. & Rene Préval issued an appeal for international aid & time / speech act / \\
& & actor \\
\hline 6b. & Earthquake devastated the country & result \\
\hline 7b. & Death toll might be above 100,000 & result / consequence \\
\hline 8b. & Magnitude 7.0 & event / circumstances \\
\hline 9b. & People trapped under collapsed buildings & result \\
\hline 10b. & Collapsed parliament & result \\
\hline 11b. & Collapsed the tax office & result \\
\hline 12b. & Collapsed schools & result \\
\hline 13b. & Collapsed hospitals & result \\
\hline 14b. & Dead people in schools & result \\
\hline 15b. & Hospitals packed with people & consequence \\
\hline 16b. & $\begin{array}{l}\text { Impossible to determine the scale of the disaster, but death toll } \\
\text { might be above 100,000 }\end{array}$ & result / consequence \\
\hline 17b. & 500,000 could be dead & result / consequence \\
\hline 18b. & 3 million people might need emergency aid & result / consequence \\
\hline
\end{tabular}




\begin{tabular}{|c|c|c|}
\hline & Topic & Topic category \\
\hline $19 \mathrm{~b}$. & Thousands homeless, sleeping in the streets & consequence \\
\hline $20 \mathrm{~b}$. & Aftershocks rocked the city & event \\
\hline $21 \mathrm{~b}$. & Governments pledged aid & speech act \\
\hline $22 b$. & $\begin{array}{l}\text { Barack Obama pledged \$10 million and promised "a swift, coordi- } \\
\text { nated, and aggressive effort to save lives" }\end{array}$ & speech act / actor \\
\hline $23 \mathrm{~b}$. & US aid: ships with helicopters and an aircraft carrier & consequence \\
\hline $24 \mathrm{~b}$. & Britain's promise of humanitarian assistance & speech act \\
\hline $25 \mathrm{~b}$. & $\begin{array}{l}\text { UK aid: } 64 \text { fire-fighters with dogs and heavy lifting equipment, fur- } \\
\text { ther assessment of needs }\end{array}$ & consequence \\
\hline $26 \mathrm{~b}$. & Gordon Brown "deeply saddened and worried" & speech act / actor \\
\hline $27 \mathrm{~b}$. & No British nationals among the dead & consequence \\
\hline $28 b$. & $\begin{array}{l}\text { Canada, China, France, Germany, Iceland, Mexico and Venezuela } \\
\text { pledge personnel, financial support and supplies }\end{array}$ & speech act \\
\hline $29 \mathrm{~b}$. & UN aid: $£ 6 \mathrm{~m}$ (emergency response fund) & consequence \\
\hline $30 \mathrm{~b}$. & French aid efforts on a "war footing" & speech act / actor \\
\hline $31 \mathrm{~b}$. & Most powerful earthquake in Haiti in 200 years & event / history \\
\hline $32 \mathrm{~b}$. & $4.53 \mathrm{pm}$ local time on Tuesday & time \\
\hline $33 \mathrm{~b}$. & About 10 miles south-west of the capital & place \\
\hline $34 \mathrm{~b}$. & Shallow tremor reason for great shaking at surface level & event / context \\
\hline $35 \mathrm{~b}$. & Poorest country in the western hemisphere & context \\
\hline $36 \mathrm{~b}$. & UN headquarters fell, possibly with $100-150$ people inside & result \\
\hline $37 \mathrm{~b}$. & Hedi Annabi and other people could be dead & result / actor \\
\hline $38 \mathrm{~b}$. & UN did not confirm the deaths & consequence \\
\hline $39 b$. & $\begin{array}{l}\text { Presidential palace, national cathedral and parliament building de- } \\
\text { stroyed }\end{array}$ & result \\
\hline 40b. & Capital's main prison collapsed, some inmates could have fled & result / consequence \\
\hline 41b. & Survivors getting themselves from under collapsed buildings & consequence \\
\hline $42 b$. & People in public squares sang hymns & consequence \\
\hline $43 \mathrm{~b}$. & Survivors lying in the streets pleaded for medical help & consequence \\
\hline 44b. & A girl (16) with the help of several men tried to rescue her family & consequence \\
\hline $45 \mathrm{~b}$. & Hospitals could not take care of all victims & consequence \\
\hline
\end{tabular}

As in some cases it was difficult to associate just one topic category to each topic, some topics were associated with more than one semantic function. The information on the number of fatalities could be an example of such double categorization. As part of the propositions concerned merely the number of people who died during the earthquake, they were associated with the function of results. However, other propositions concerned not only those who died during the earthquake but also those who could die due to sickness or the rescue coming too late. These propositions, often expressed in the future tense and/or with the use of modal verbs, could concern both results (direct outcome of the earthquake) and consequences (an outcome of what happened after the earthquake), e.g.: [...] liczba ofiar mozie przekroczyć 100 tys. [the death toll may rise above 100 thousand], [...] quake death toll could rise above 100,000, Ofiar trzęsienia ziemi może być 
ponad 100 tys. [There may be over 100 thousand fatalities] or [...] 500,000 might be dead. Also the topic of a collapsed prison and inmates that could have fled expressed in the following proposition: [...] the capital's main prison had also collapsed, allowing some inmates to flee could concern both direct results of the earthquake (the collapsed building) and the consequences thereof (fleeing inmates). Therefore, all the topics identified by propositions or sentences that could be interpreted in two ways, were associated with two topic categories.

The researchers hesitated whether to include the topics in the lists as many times as they were mentioned in the texts or not. However, as the repeatability of certain topics is meaningful at a later stage of the analysis it was decided to present the topics as many times as they occur.

The reason for referring to the collapsed buildings in one topic in Table 1: (19a.) Budynek parlamentu, głównego urzędu podatkowego, szkoły i szpitale zawalone [The buildings of parliament, tax office, schools and hospitals collapsed], and in four separate topics in Table 2 (10b.) Collapsed parliament, (11b.) Collapsed tax office (12b.) Collapsed schools and (13b.) Collapsed hospitals is that in the Polish text the buildings are named in one sentence, whereas in the British text in four separate sentences.

Figure 1 and Figure 2 on next page represent the hierarchical structure of the topics listed in Table 1 and Table 2, and as such demonstrate the thematic structures of the studied texts.

Looking at the figures one can observe that the overall construction of the thematic structure of the Polish text and the thematic structure of the British text is similar. In both cases the news episode is the Haitian earthquake, both schemes include elaborate categories of main events and consequences and they both somehow neglect the conditions/causes of the event. The only topic that refers to history concerns the tremor having been the biggest in about 200 years, and the only two topics that refer to context are the poverty in Haiti and, in case of The Guardian, the tremor having been shallow (and having caused great damage).

Also the structure of the main events including the setting and happenings is similar in both cases. Both dailies mention individual events, their participants and results, as well as consequences. They both give the time and place of the event and name the circumstances.

However, apart from all the similarities, the structures are far from identical. The most profound difference in the occurrence of the semantic categories can be observed in the class of consequences. While the British daily names both acts and speech acts, the Polish daily omits the speech acts, focusing merely on acts.

Looking into the individual semantic categories one is able to observe more differences. The two dailies published contradictory information on the time that had passed since last such powerful tremor; it had been 240 years according to Gazeta Wyborcza and 200 years according to The Guardian. Moreover, the British daily claims that the event happened at $16.53 \mathrm{pm}$, while the Polish daily gives an approximate time of the earthquake $(17.00 \mathrm{pm})$. Also the information on the place of the event given by The Guardian is more precise, though it is expressed 


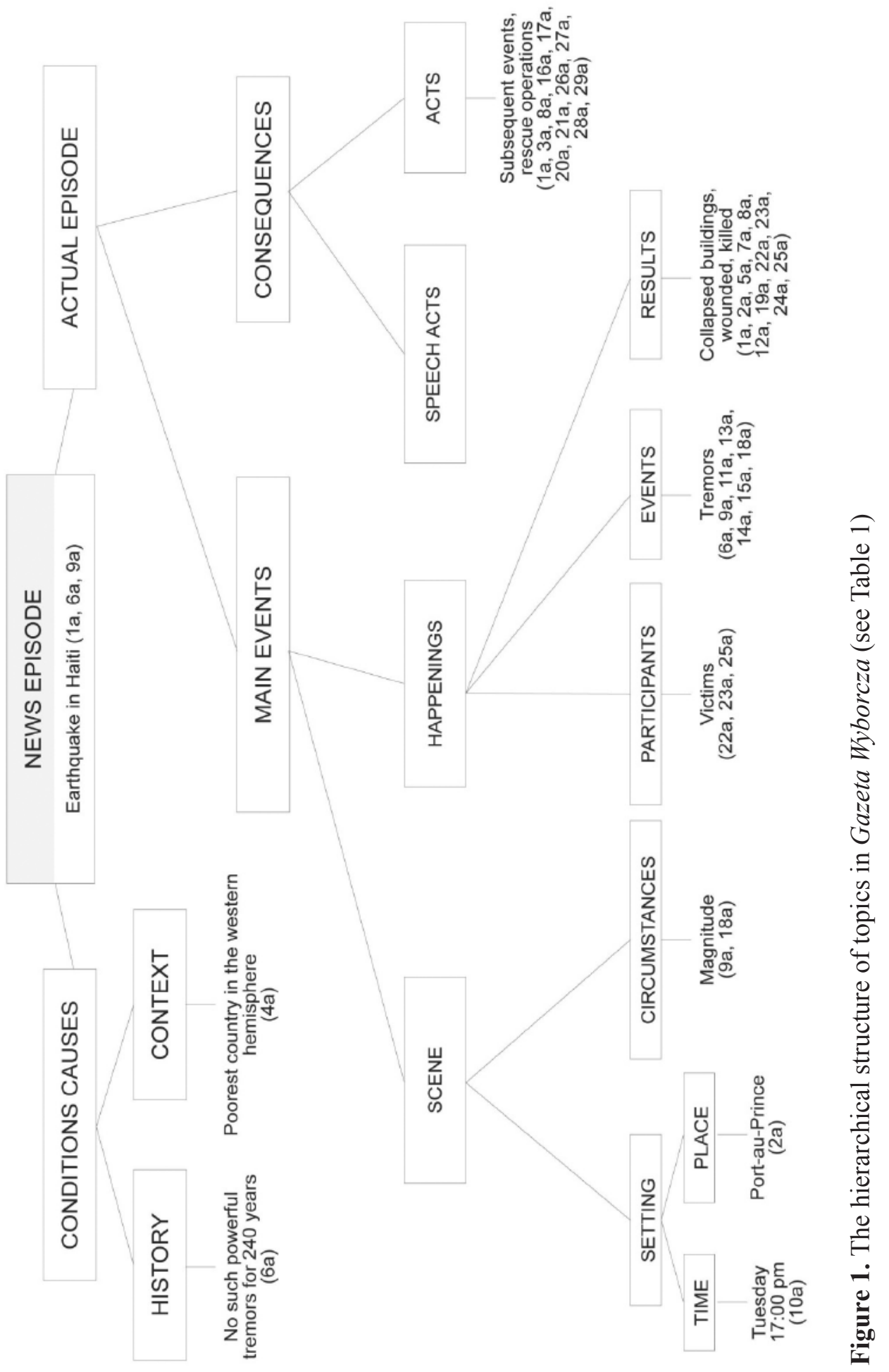




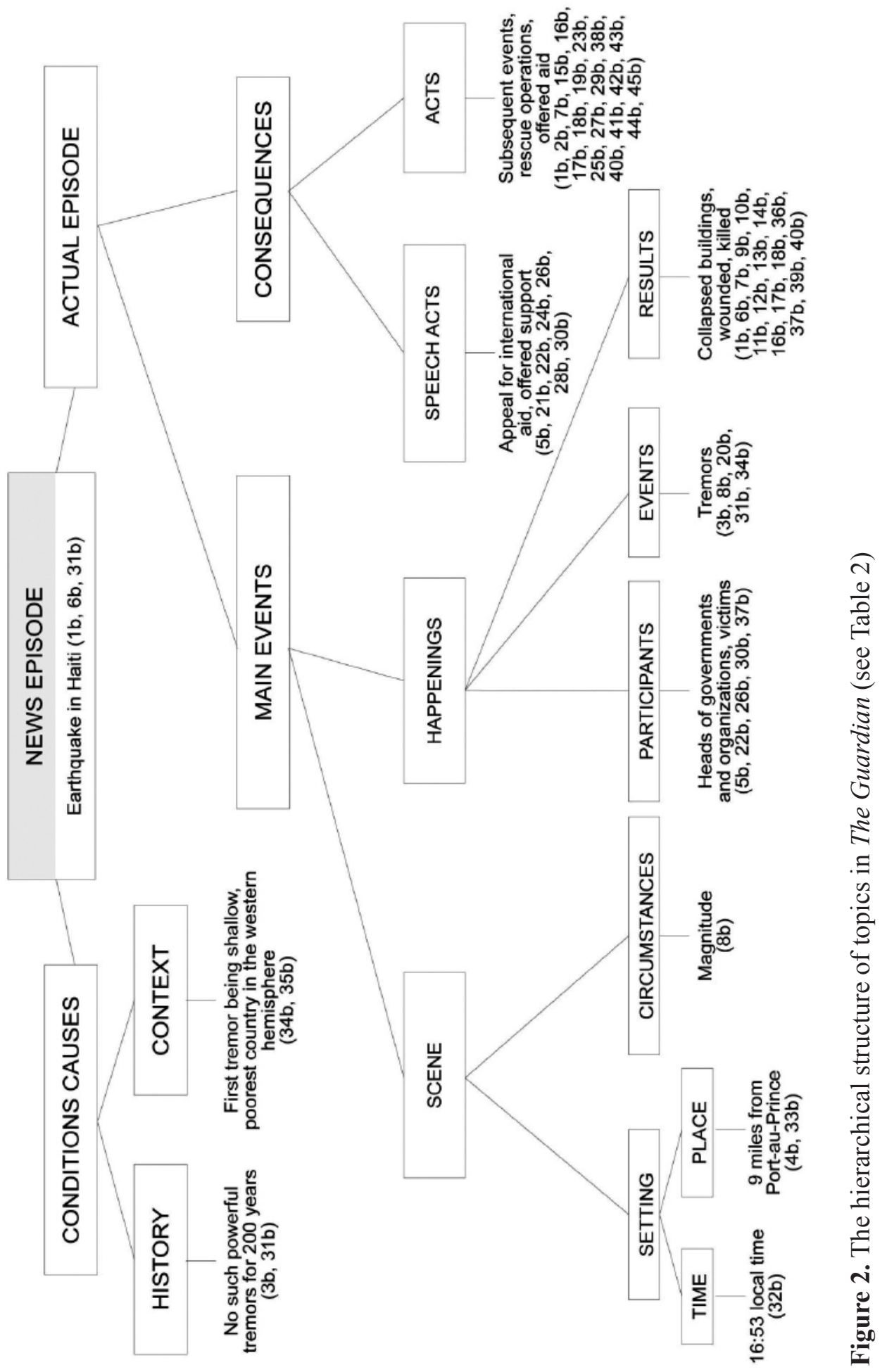


differently at the beginning and in the later part of the text. First, it is nine miles from the capital, then about ten miles south-west of Port-au-Prince.

Furthermore, the British thematic structure features topics missing in Gazeta Wyborcza, namely Rene Préval's appeal for international aid and the support promised to Haiti. More importantly, this leads to the occurrence of additional participants of the event in the British texts, i.e. the heads of governments or international organizations pledging help.

As mentioned above, some topics are brought up more than once in both texts. Gazeta Wyborcza points out twice that ofiar może być ponad 100 tysięcy [death toll might be above 100 thousand], that zawality sie setki, a być może tysiace domów [hundreds or even thousands of houses collapsed in the capital] and that zasypanych odkopywano gotymi rękami [the buried were dug out with bare hands]. The Guardian repeats some topics even more. It states that the death toll could rise above 100,000 three times and mentions the place of the event and the time that had passed since last such powerful tremor twice. Moreover, it repeats the topic of collapsed schools and hospitals and the information that the hospitals were packed with the victims. Also, the topic of the collapsed building of the parliament appears twice.

Yet more differences can be found between the two thematic structures within the topic of the death toll. Both dailies give an estimate of 100 thousand but they also provide the reader with two other dissimilar numbers. The Polish text features information on 30 to 50 thousand dead and the British one on 500 thousand. Moreover, in topics 18a. and 20b. one can observe differences within the semantic category of events. While Gazeta Wyborcza mentions the quantity and magnitude of the aftershocks, The Guardian does not.

The results of the main event, namely the collapsed buildings, are also treated differently in the studied texts. The topics listed in Table 1 and organized into a thematic structure presented in Figure 1 concern both private houses and public buildings, whereas topics in Table 2 refer only to public buildings such as schools, hospitals, the parliament, the tax office, UN headquarters, the presidential palace, the cathedral or prison.

The topics that are present only in the British text, concerning the international aid for Haiti, contain many details such as the amount of financial support, the supplies or the number of rescuers. Much attention is paid to the names increasing the news value (Lippmann 1960; Galtung and Ruge 1965; Conboy 2007) of the article, as Gordon Brown and Barack Obama are quoted in the text. The Guardian also mentions the reaction of the British government to the event, while the Polish daily does not present the stand of the Polish authorities.

Moreover, the British text includes the topics of the people who gathered to sing hymns and of the tremor being shallow. It also mentions the topic of the efforts of individuals coping with the situation such as the story of a 16-year-old rescuing her family. However, the Polish daily gives a more elaborate account of the happenings of the first tremor, namely describes the windows falling out, walls trembling, houses collapsing and cars falling down a hillside. 
As important as the content of the semantic categories and the topics is the order in which they are presented in the texts, especially as it can be influenced by the cultural values characteristic to Poland and the United Kingdom. The order in which individual categories appear in the text is partly consistent with van Dijk's assumptions as he states that first (in the headline) there usually comes the main event, to be followed by causes, history and context. And indeed, the main event (the earthquake) comes up in the headline of both articles. However, history and context are also located at the top of each list of topics. In Gazeta Wyborcza context appears in (4a.), and history, which takes up the third position in The Guardian, appears in (6a.). The participants and speech acts are also placed on the top of the list of the British topics in (5b.).

The first ten topics in the Polish text are:

1. death toll

2. place of the earthquake and the number of collapsed houses

3. digging out the victims

4. poverty in Haiti

5. damages

6. no such powerful tremors for 240 years

7. death toll (again)

8. death toll (again)

9. magnitude

10. time of the earthquake.

The first ten topics in The Guardian are:

1. death toll

2. search for survivors in collapsed buildings

3. no such powerful tremors for 200 years

4. place of the earthquake

5. president's appeal for international aid

6. damages

7. death toll (again)

8. magnitude

9. search for survivors in collapsed buildings (again)

10. the parliament building collapsed.

Comparing the topics listed above one can observe that both Gazeta Wyborcza and The Guardian place death toll at the top of the story and then inform about the collapsed buildings. The location of the topics of the magnitude, search for survivors (or digging them out) and the damages is also similar in both dailies. However, the place of the earthquake is given earlier in the Polish text and so does the time of the earthquake (tenth topic in Gazeta Wyborcza). The topic of poverty in Haiti appears only at the beginning of the Polish article, and Préval's 
appeal merely in the British text. The fact that no such powerful tremor occurred in Haiti for some 200 years is placed higher in The Guardian.

It is worth paying attention to the fact, that poverty in Haiti does not appear in the British text until (35b.) and the time of the earthquake until (32b.).

\section{Analysis of cultural context to the thematic structure of news}

With the analysis of the thematic structure of selected news texts we demonstrated that even though the studied articles share some similarities (the same news episode, extended main events and consequences, neglected conditions/causes, similar main events), one may also observe significant differences.

The disparities concern the description of results and events and the order in which the topics are mentioned. In the British text there appear two classes of consequences, namely acts and speech acts, and the category of context is wider. The Guardian introduces more topics and gives more precise time and place of the event. Moreover, the frequency of repetition of individual topics is higher. Also, in the British text much attention is paid to names increasing the news value.

In the Polish text there is only one class of consequences, namely acts. The topic of international help for Haiti is omitted, however, the text includes a more elaborate account of the happenings of the first tremor. Last but not least, Gazeta Wyborcza mentions fewer participants of the event.

Below we describe the possible relationship between the differences found between the thematic structures of the two texts, and the cultural values characteristic of Poland and the United Kingdom within the framework of Hall's division of societies into high-context and low-context cultures and the cultural dimensions proposed by Hofstede and Hofstede.

As mentioned above, the content of the headlines and the subheadings as well as the number of the subheadings differ between the studied texts. As the Polish headline is shorter it might be concluded that since it was produced in a highcontext culture, more information is coded within fewer words. Also as Polish culture is polychronic, more topics are brought up on the front page of the Polish daily. Both fragments concern the death toll, collapsed buildings and searching for or rescuing the buried and they both give the place of the event. However, while The Guardian adds just one piece of information (concerning the fact that it was the biggest tremor in 200 years), Gazeta Wyborcza gives the time of the event, the number of inhabitants of Port-au-Prince, the number of collapsed houses and covers the topic of how the survivors were rescued.

The overall correspondence of the two studied structures could be easily explained with the fact that the two cultures in question share masculine values and short-term orientation. In both articles the scale of the tragedy is mentioned (i.e. the death toll and the number of collapsed buildings, the magnitude of the earthquake and the extent of the damage) which is characteristic of masculine cultures. Moreover, analogous location of the category of history in the texts and the inclu- 
sion of information on current situation in Haiti could be considered typical of cultures with short-term orientation.

The disparities between the texts, on the other hand, may stem from the cultural differences existing within the dimensions of power distance, individualism vs. collectivism and uncertainty avoidance, as well as from the distinct role that the context plays in the processing of information in the two cultures.

It should be noted that especially the disparities in the number and the character of details introduced in both texts may be caused by different use of context in the two cultures. As in high-context cultures a more ornate style of language is used to illustrate events, in the Polish text we can find vivid descriptions of what happened in Haiti during the first and most powerful tremor. Thus, the reader is brought (emotionally) closer to the events. In the British text, produced in a lowcontext culture, the given details are more factual. They concern precise time and place of the event and the reason for such great extent of damage. The last topic in The Guardian may also be connected with high individualism of the British culture, in which the subject of guilt plays a significant role.

Surprisingly, a more precise date of last such powerful tremor is given in the Polish text. It might be assumed that since British low-context culture values high dynamism, the attention that is paid to details concerns only the recent events. However, this seems a farfetched conclusion.

It is also unclear why the topic of the time and the context of the event come later in the British text than in the Polish text, which would suggest low relevance of this information. Admittedly, the information on the time is implied in topic (5b.), however it refers to the president's appeal for aid, and not the main event.

The low-context characteristic of the British culture may also be manifested in larger number of repeated topics, as in a low-context culture any information needs to be placed in much context, and that often leads to the repetition of this information.

It is interesting that the topic of the president's appeal for help and the international aid offered to Haiti is presented only in the British text, since it seems that such information is easily accessible as both those pleading for help and those pledging help usually turn to the media for coverage. The presence of this topic in The Guardian could be explained easily as the text was produced in a low-context, highly individualistic British culture with low uncertainty avoidance, especially since dedication to factuality and valuing information on finances and statements of public figures are typical for such cultures. Moreover, it is characteristic for cultures with low uncertainty avoidance to emphasize the positive aspects of any event, such as the offered aid, and for highly individualistic cultures to value social engagement in helping those in need. Since Polish culture is characterized as a high-context, slightly individualistic culture with high uncertainty avoidance, the topic in question may simply present low news value to the Polish reader.

The fact that the category of speech acts was covered only by The Guardian could be related to the text having been produced in a low-context culture. As in such cultures much attention is paid to the accuracy of the reported text, citations must be common. And indeed, there are numerous quotations and references to 
various statements in the British text. Predominantly, they concern information of high news value, such as the number of casualties, reason for extensive damage or size of the financial support. The quotations in the Polish article are less common and regard the accounts of the witnesses of the first tremor, which impart a sense of emotionalism to the text.

The larger number of participants and a high location of the thematic category of actor in the British text may also stem from British high individualism, as in individualistic cultures the doer of an action is almost as important as the action itself. It would also be reasonable to claim that the way the collapsed buildings are referred to in the studied texts is consistent with the different level of individualism characteristic of the studied cultures. While The Guardian mentions only public buildings, Gazeta Wyborcza comments on both public buildings and private homes, bringing the subject somewhat closer to family values (typical of collectivist societies).

All in all, there is one more disparity that should be mentioned here, even though it does not directly concern the thematic structure of the texts, namely the difference in their size. The fact that the British text is much longer than the Polish one (an unusual disparity of 740 words in The Guardian and 445 words in Gazeta Wyborcza) might suggest that the news value of this story is higher in the United Kingdom. Although the coverage of domestic disaster stories in high uncertainty avoidance cultures is usually considerable, the Haitian story is not discussed extensively in Gazeta Wyborcza. This may stem from the fact that the distance between Poland and Haiti is long enough and the possibility of an earthquake occurring in Poland faint enough not to provoke anxiety among Polish readers.

\section{Frequencies of themes - quantitative data}

The qualitative analysis of the thematic structure can be also supported by some quantitative data concerning the frequency of occurrence of the most important topics. Prior to the analysis, all propositions concerning these themes were counted. Theme (c.) concerns all those affected by the earthquake including the dead, wounded and homeless. The data are presented in Table 3 and Figure 3.

Table 3. Frequencies of themes in front-page articles published in Gazeta Wyborcza and The Guardian (January 14, 2010) - quantitative data

\begin{tabular}{|l|c|c|}
\hline \multirow{2}{*}{ Theme } & Gazeta Wyborcza & The Guardian \\
\cline { 2 - 3 } & No. of occurrences & No. of occurrences \\
\hline a. aftershocks & 1 & 1 \\
\hline b. appeal for aid & 0 & 2 \\
\hline c. casualties & 17 & 20 \\
\hline d. collapsed buildings & 11 & 14 \\
\hline e. earthquake & 3 & 7 \\
\hline f. offered aid & 0 & 16 \\
\hline g. rescuing survivors & 2 & 1 \\
\hline
\end{tabular}




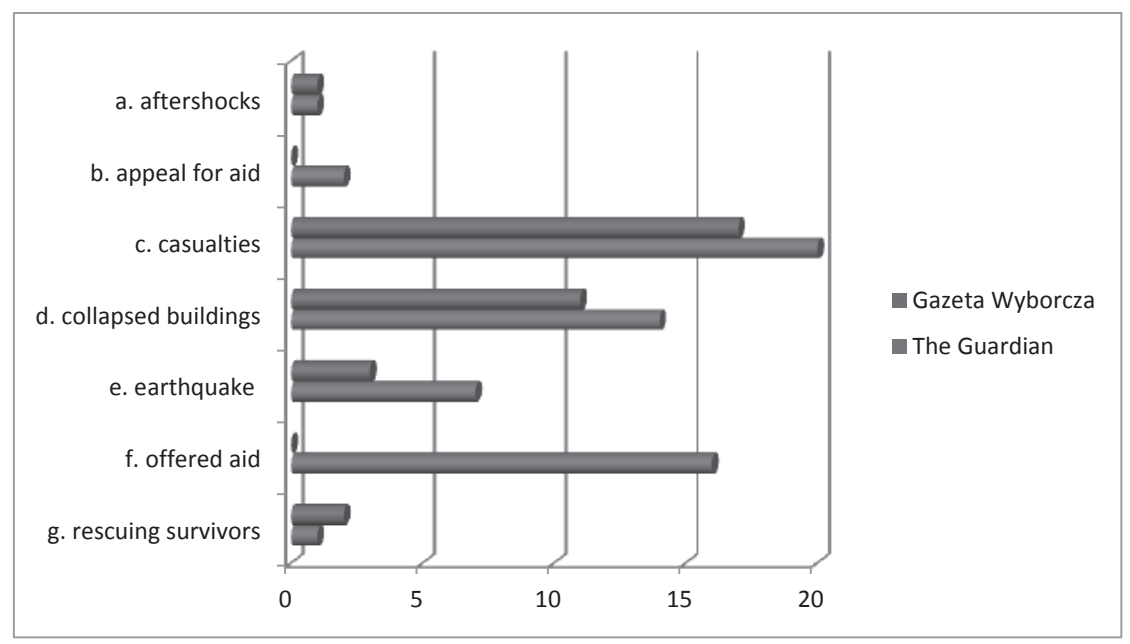

Figure 3. Frequencies of themes in front-page articles published in Gazeta Wyborcza and The Guardian (January 14, 2010) - quantitative data

The results of the quantitative study confirm the conclusions drawn in the course of the qualitative analysis. The most frequent theme in both texts is the topic of the casualties (including all affected participants). Taking into account the length of the texts, little difference can be observed in the occurrence of this theme in the two dailies. The frequency of the themes concerning the collapsed buildings and aftershocks is also similar.

The preponderance of the propositions on theme (f.) (and also (b.)) in The Guardian is typical, as it was noted above, of low-context, highly individualistic cultures with low uncertainty avoidance.

The high frequency of the main theme, i.e. the earthquake and the details thereof, in the British text, also points to a low-context culture, in which dedication to factuality and meticulousness are highly valued.

The only theme that may be found more often in the Polish text concerns rescuing survivors. This may stem from high uncertainty avoidance of this culture, as the Polish reader seems to be interested in the actions aimed directly at helping the victims, and especially those whose situation is unstable or unknown.

\section{Conclusions}

Most differences between the thematic structures of the studied texts correspond to the cultural differences existing between Polish and British cultures. As the two cultures differ mostly in the dimensions of uncertainty avoidance and individualism vs. collectivism and one is a low-context culture and the other a high-context culture, the values characteristic of those dimensions or context-related classifica- 
tion can be accounted for most of the disparities between the studied structures.

However, not all the differences can be explained with cultural dissimilarity of the two dailies. Undoubtedly other factors, such as individual features of the editorial teams, accessibility of the information, and political and financial aspects could prove to be just as significant.

Some differences could be also observed between van Dijk's thematic structure of the Gemayel assassination story and the thematic structures in this study. These are most likely caused by the fact that they represent different cognitive situational models: the event of a political assassination and the event of an earthquake. As in the first case the causes for the event, i.e. the history and context, are crucial to the story, in the second case the cause is quite obvious, as it is the force of nature.

Even though applying the model of cultural dimensions to such a multicultural society as the British one might seem surprising, such choice is well founded taking into account the dominating position of the English language on the international arena. The study was conducted among the British and therefore the scores should be treated as representative of the British culture. Moreover, the research conducted by Geert Hofstede in the 1970s was numerously replicated and as the authors of the last edition of Cultures and Organizations. Software of the Mind claim "the IBM national dimension scores [...] have remained as valid in the year 2010 as they were around 1970" (Hofstede, Hofstede and Minkov 2010: 39).

In this paper we mainly focused on the differences between the texts produced in the two cultures in question. Yet this is not to state that the British and the Polish news texts are radically different. On the contrary, they both concern the same event, provide similar information and their thematic structures resemble each other. This seems to be congruent with the cultural dimensions model as both cultures are described as masculine and their place on the long-term/short-term orientation axis is similar.

The objective of this article was to find out if cultural values are among the factors shaping the form and content of news texts. The analysis could obviously be extended to embrace the schematic structures of the texts analyzed. Also the topic categories of actor, time and place could be studied in greater detail. However, given the limited space of the article, the analysis had to be brief. Hopefully, it will be enough to encourage further discussion on the relationship of culture and the form and content of news texts.

\section{Acknowledgements}

This paper was financed by the Polish Ministry of Science and Higher Education research grant (N N104 055939). 


\section{References}

Addlay, Esther and Rory Carroll (2010) "Haiti's day of devastation". The Guardian, January 14, front page, London and Manchester edition.

Barker, Chris and Dariusz Galasiński (2001) Cultural Studies and Discourse Analysis. A Dialogue on Language and Identity. London, Thousand Oaks, New Delhi: SAGE Publications.

Bell, Allan (1998) "The discourse structure of news stories". In: Bell, Allan and Peter Garrett (eds.). Approaches to Media Discourse. Oxford, Malden, MA: Blackwell Publishers Ltd, 64-104.

Bosacki, Marcin (2010) "Koszmar Haiti”. Gazeta Wyborcza, January 14, front page, national edition.

Bremer, Katharina, Celia Roberts, M.T. Vasseur, Margaret Simonot and Peter Broeder (1996) Achieving Understanding: Discourse in Intercultural Encounters. London: Longman.

Collier, Mary Jane (ed.) (2000) Constituting Cultural Difference Through Discourse. Thousand Oaks, California: Sage Publications.

Conboy, Martin (2007) The Language of the News. Abingdon: Routledge.

Detweiler, Richard, Richard W. Brislin and William McCormack (1983) "Situational analysis". In: Landis, Dan and Richard W. Brislin (eds.) Handbook of Intercultural Training, vol. 2: Issues in Training Methodology. New York: Pergamon.

Duszak Anna (1998) Tekst, dyskurs, komunikacja międzykulturowa. Warszawa: Wydawnictwo Naukowe PWN.

Ferris, S. Pixy and Susan H. Godar (2006) Teaching and Learning with Virtual Teams. London: Information Science Publishing.

Fitzgerald, Helen (2003) How Different Are We? Spoken Discourse in Intercultural Communication. Clevedon, England: Multilingual Matters.

Galtung, Johann and Mary Ruge (1965) "The structure of foreign news". Journal of Peace Research 2, 64-90.

Gannon, Martin J. and Rajnandini Pillai (2010) Understanding Global Cultures: Metaphorical Journeys through 29 Nations, Clusters of Nations, Continents, and Diversity, $4^{\text {th }}$ ed. London: SAGE Publications.

Hall, Edward Twitchell (1976) Beyond Culture. New York: Anchor Books.

Hofstede, Geert, Gert Jan Hofstede and Michael Minkov (2010) Cultures and Organizations: Software for the Mind. New York: McGraw Hill.

Hofstede, Geert and Gert Jan Hofstede (2005) Cultures and Organizations: Software for the Mind. New York: McGraw Hill.

Kintsch, Walter and Edith Greene (1978) "The role of culture - specific schemata in the comprehension and recall of stores". Discourse Processes 1, 1-13.

Lippmann, Walter (1960) Public Opinion. New York: The Macmillan Company.

Reynolds, Ralph E., Marsha A. Taylor, Margaret S. Steffenson, Larry L. Shirley and Richard C. Anderson (1982) "Cultural schemata and reading comprehension", Reading Research Quarterly 3, 353-366.

Scollon Ron. and Susan Wong Scollon (2001) Intercultural Communication: A Discourse Approach, $2^{\text {nd }}$ ed. Malden, MA; Oxford: Blackwell.

Van Dijk, Teun A. (1988) News Analysis. Case Studies of International and National News in the Press. Hillsdale, NJ: Lawrence Erlbaum Associates.

Wierzbicka, Anna (2003) Cross-cultural Pragmatics: the Semantics of Human Interaction. Berlin and New York: Mouton de Gruyter.

Wood, Steve (2004) Germany and East-Central Europe. Political, Economic and Socio-Cultural Relations in the Era of EU Enlargement. Burlington: Ashgate Publishing. 
ANNA ZIĘBA has recently gained a doctorate from the Institute of Linguistics at Adam Mickiewicz University. She holds an MA in applied linguistics. Her research includes studies of culture-based differences occurring between languages at the level of pragmatics and semantics. Her study of modern news texts is a part of a research project funded by the Polish Ministry of Science and Higher Education. In 2010 she was also awarded the Clifford and Mary Corbridge Trust Scholarship (Cambridge University).

Address: Dr Anna Zięba, Institute of Linguistics, Adam Mickiewicz University, Al. Niepodleglosci 4, 61-874 Poznan, Poland. [email: azieba@amu.edu.pl] 